\title{
THREE EARLY TROPICAL FIELD EXPERIMENTS
}

\author{
Michael Garstang, Edward Zipser, Robert Ellingson, Kenneth Warsh, \\ Peter Grose, Stanley Ulanski, Ronald Holle, Ward Seguin, David Fitzjarrald, \\ Steven Greco, and George D. Emmitt
}

\begin{abstract}
Together with the transformational arrival of the geostationary satellite in 1967, we recall the impact of a new era of tropical atmospheric field research examining interactions between the ocean and atmosphere.
\end{abstract}

T he tropics occupy a vast expanse of Earth's surface, covering tens of millions of square kilometers. Geographically bounded by the Tropics of Cancer and Capricorn, $80 \%$ of this region consists of ocean. Meteorologists have long recognized the importance of this coupled atmosphereocean system influencing Earth's climate. The years 2017-19 mark the fiftieth anniversary of a 3-yr period of research of the tropical atmosphere that contributed to the advancement of knowledge over the next half century. In this article, we take up the quest at the beginning of the modern era of geosciences with the advent of space-based platforms and the emergence of electronic recording, transmission and computational systems. We have chosen elements from each of three contiguous field programs to illustrate findings and approaches from each experiment that had enduring influence on subsequent field programs and indeed to the improved understanding of the ocean-atmosphere system in the tropics.

Tropical weather is particularly dependent upon interacting scales of motion and feedback processes that range from the turbulent to the planetary. While significant elsewhere in the atmosphere, these scale interactions are critical to the understanding of the weather in the tropics. Adequate quantitative
AFFILIATIONS: GARSTANG—Department of Environmental Sciences, University of Virginia, and Simpson Weather Associates, Inc., Charlottesville, Virginia; ZIPSER-Department of Atmospheric Sciences, University of Utah, Salt Lake City, Utah; ELLINGSON-Department of Earth, Ocean and Atmospheric Science, Florida State University, Tallahassee, Florida; WARSH-Escondido, California; Grose-Gambrills, Maryland; ULANSKI-Department of Geology and Environmental Science, James Madison University, Harrisonburg, Virginia; HolleHolle Meteorology and Photography, Oro Valley, Arizona; SeguinEtowah, North Carolina; FItZjARRALD-Atmospheric Sciences Research Center, University at Albany, State University of New York,
Albany, New York; Greco AND EMmitT-Simpson Weather Associates, Inc., Charlottesville, Virginia CORRESPONDING AUTHOR: Dr. Michael Garstang, mxg@swa.com

The abstract for this article can be found in this issue, following the table of contents. DOI:10.1175/BAMS-D-18-0151.I

In final form 6 July 2019

(0)2019 American Meteorological Society

For information regarding reuse of this content and general copyright information, consult the AMS Copyright Policy. 
measurements of the relevant variables on any continuous temporal and spatial basis that resembles the operational networks of the temperate latitudes does not exist over these tropical marine regions. Advances in the science of tropical meteorology have been hindered by the absence of such operational observing networks. Instead smaller spatial regions have been targeted over limited time periods to gather specific data to address a given set of questions. (See the "Fragmentary data over tropical oceans before the satellite era: Hurricane Janet, 21 September 1955, as a case in point" sidebar.)

The dawn of the space age signaled the arrival of remote sensing on the scale of the planet's fluid systems. Whereas meteorological satellites had and still have a protracted evolution, they provided access to the remote oceans of the tropics. Three experiments, the 1967 Line Islands Experiment, the 1968 Florida State University Barbados Experiment, and the 1969 Barbados Oceanographic and Meteorological Experiment (BOMEX), initiated a new phase in tropical atmospheric-oceanic field work, which employed multiple platforms (satellites, ships, aircraft, buoys, towers, free-flying and tethered balloons, and more), exploring details of how the oceans and the atmosphere were linked.

Important elements of these three experiments are described below together with their connections to such major experiments as the Global Atmospheric
Research Program (GARP) Atlantic Tropical Experiment (GATE) in 1974 and the Tropical Ocean and Global Atmosphere Coupled Ocean-Atmosphere Response Experiment (TOGA COARE) in 1992.

\section{THE LINE ISLANDS EXPERIMENT (1967).}

The Line Islands Experiment (LIE) was the first of the three tropical ocean field campaigns of 1967, 1968, and 1969, "designed to attack the central problem of scale interactions, especially the role of convective and mesoscale systems" (Zipser 1970). These three experiments were all purposeful preparations for the GARP and were early steps in carrying out the vision articulated by Jule Charney and many others. In the original "Charney report" (Perry 1975), this ambitious global effort would be required, and emphasized the need for parameterization of tropical convection if general circulation models were ever to approach their potential.

The LIE was located on three islands between $2^{\circ}$ and $6^{\circ} \mathrm{N}$ in the central tropical Pacific primarily for logistical reasons, but Verner Suomi was especially enthusiastic that the data would be obtained close to the first geosynchronous satellite [Applications Technology Satellite 1 (ATS-1)] subsatellite point. These first images indeed proved to be a revelation. For the first time, we had a near-global view stretching from the close to convection-free subsidence of the subtropical highs, through the (mostly) trade wind belts

\section{FRAGMENTARY DATA OVER TROPICAL OCEANS BEFORE THE SATELLITE ERA: HURRICANE JANET, 2I SEPTEMBER 1955, AS A CASE IN POINT}

$\mathrm{Ne}_{\mathrm{i} e}$ 2300 local time, the meteoroNogical assistant at Trinidad's Piarco Airport Forecast Office had just plotted a lone ship's report near $13^{\circ} \mathrm{N}$ and $57^{\circ} \mathrm{W}, 3^{\circ}$ of longitude east of Barbados. Few ship reports were seen in the latitude of the central tropical and equatorial Atlantic between the Caribbean and western Africa.

Nothing was remarkable about this single ship's observation except its appearance and northerly tilt to its I8-kt $\left(\mathrm{l} \mathrm{kt} \approx 0.5144 \mathrm{~m} \mathrm{~s}^{-1}\right)$ wind report. Nonetheless, it gave Garstang, the duty forecaster, some considerable pause for thought. Could it be an incipient hurricane? Would it intensify? With a forward speed of $15 \mathrm{kt}$, it would impact Barbados in less than $10 \mathrm{~h}$, crossing the island by noon only 12 hours away! No time to be lost, he decided to immediately send a full-blown hurricane warning to Barbados.

Janet passed just south of the island near noon on 22 September with $110-120-\mathrm{mph}$ (180-190 kph) winds and a 7-ft $(2.1 \mathrm{~m})$ storm surge. Between 38 and 57 deaths were reported with over 8,000 homes damaged at a cost of $\$ 500$ million (U.S. dollars). But for a single ship report, the casualties and damage could have been much higher.

The sequence of events reported above are based upon Michael Garstang's personal recall (they differ in detail from reports in https:// en.wikipedia.org/wiki/Hurricanejanet). But in point of fact, the state of tropical meteorology in those days suffered not only from lack of data, but from lack of communication of data potentially available, and inadequate coordination between different forecast offices. At about the same time as the above ship report available to Trinidad was received, a different ship report showing near-hurricane-force winds was available elsewhere but apparently not shared. Last but not least, the prevailing wisdom of the day was that a disturbance strong enough to threaten the Lesser Antilles would have been detected in the mid-Atlantic shipping lanes, which likely accounted for the lack of reconnaissance aircraft being dispatched; the possibility of sudden, rapid intensification near the Antilles was apparently not well recognized. These advances awaited the dawn of the weather satellites and the improved understanding that field campaigns would generate. 
Some 70 students, faculty, and families (including Jchildren), were flown to Barbados from Tallahassee, Florida, in the largest cargo aircraft in the U.S. Air Force. This aircraft was equipped with the biggest radial engines ever built. Passengers sat on canvas seats lined up against the thin uninsulated aluminum sides of the aircraft, which did nothing to reduce the deafening roar of the four giant engines. At least one of the students had never been beyond the boundaries of the state of Florida and more than one never outside the limits of the United States. Few had flown on a cargo plane and all were somewhat disturbed when approaching San Juan, Puerto Rico, to overhear on the intercom the captain tell his engineer to feather engine No. 3 so that the propellers still rotated so that the civilians on board would not know that the engine had failed. We were carrying 14 tons of cargo and would only have one shot at landing. We could not take off on three engines.

Systems on Barbados required $24 \mathrm{~h}$ presence of observers so that students would be at remote sites throughout the night. At locations like East Point (Fig. I), there was no light pollution. The nights were black and the clacking of largeclawed land crabs against the coral limestone was an eerie accompaniment to the roaring of the Atlantic surf against the

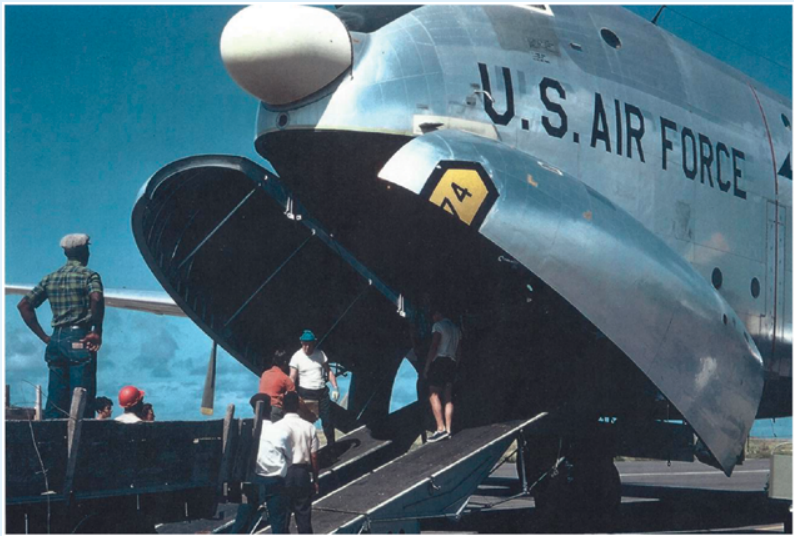

FIG. SBI. Georgia Air National Guard C-I24 aircraft used to transport personnel and equipment to Barbados (Florida State University 1968 experiment photographic archives).

nearby coral cliffs. Yet the Milky Way was a brilliant ribbon of light and the Andromeda galaxy a three-dimensional blaze of color. To one graduate student from New York, this was his first clear view of the Milky Way. with little more than shallow trade cumulus unless some disturbance interrupted the general subsidence there as well, to the variable occurrence of deep convection in the equatorial trough zone.

It was those first animations from ATS- 1 that indeed demonstrated that synoptic disturbances in the deep tropics had important variability on all time scales, and that treating them as steady-state systems had to be done with caution. For the first time, these animations revealed complex temporal and spatial variability that made it a challenge to track them as coherent weather systems over several days (or sometimes even for one day). Rather than anticipating a synoptic-scale disturbance to arrive by tracking, it became more expedient to simply schedule repetitive flight patterns day after day, which on many occasions were rewarded with unanticipated deep convection.

These repetitive flight patterns were used to great advantage in planning the 1968 and 1969 aircraft operations, and later during GATE (1974). Recognizing the importance of data in the mixed layer, the first half of these flights were often at 150-m altitude, with later portions usually at $3 \mathrm{~km}$. By flying daily, and not attempting to divert around the ubiquitous convective showers (mostly from lack of knowledge of how to avoid them), we slowly discovered that the turbulence in this equatorial convection was usually light to moderate. This experience was repeated in Barbados 1968 and BOMEX 1969, leading to the successful multi-aircraft program

1972b). 
during GATE, during which 13 aircraft from 7 nations accumulated a huge database from which LeMone and Zipser (1980) were able to characterize

\section{BARBADOS}

os Barbados, named for the island's bearded fig tree

Ly the Portuguese en route to Brazil, is a unique island some $90 \mathrm{mi}$ due east of St. Vincent.

The first English ship under Captain John Powell made landfall on Barbados on 14 May 1625. Settled two years later and remaining tied to England for the next 400 years, Barbados is the third oldest parliamentary democracy in the world and the first parliament in the Western Hemisphere.

This unique island differs from the rest of the Caribbean Islands not only in its geology and geomorphology, consisting of low-lying coral limestone only $300 \mathrm{~m}$ in elevation but in the scientific and technological fields as well. Barbados has a long history of supporting societies in astronomy, agriculture, horticulture, meteorology and together with research institutions, representing Caribbean and overseas institutions such as the Caribbean Meteorological and Hydrological Institute, the McGill Biological Institute, the University of Miami Dust Program, the McGill High Altitude Research Program, and the Cloud Observing Program.

Each of these programs have contributed to their specialized fields in remarkable ways.

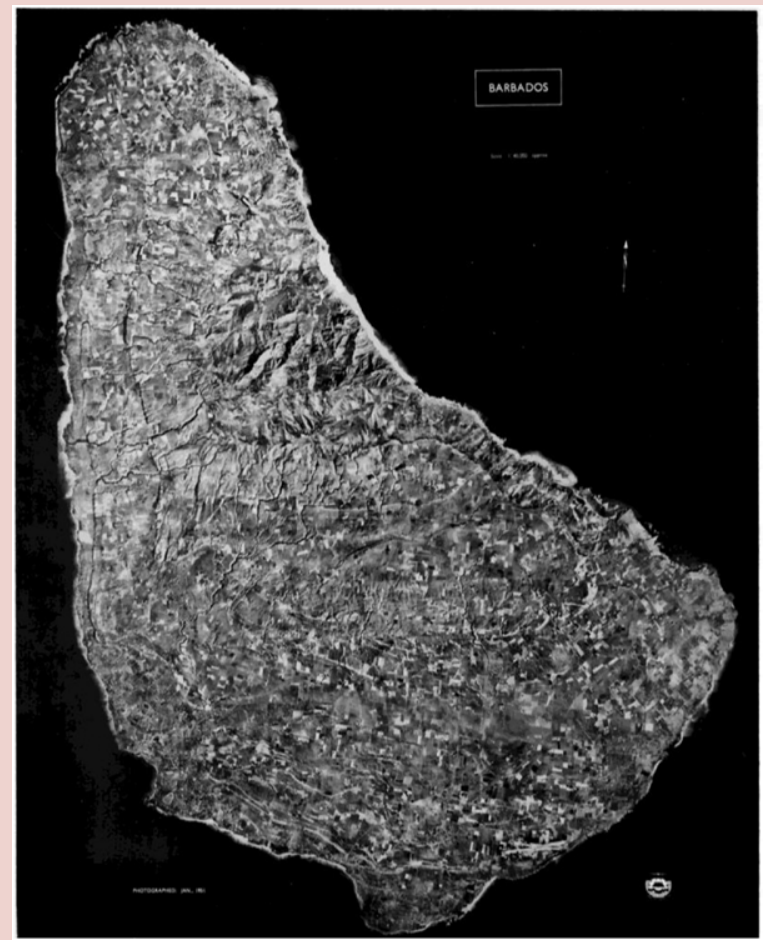

FIG. SB2. Composite aerial photograph of the island of Barbados (Florida State University 1968 experiment photographic archives). tropical oceanic convective updrafts and downdrafts as a function of height, a database still used today.

Mesoscale systems with unsaturated downdrafts were encountered by the aircraft (Zipser 1969). Without the animations from the ATS-1 satellite, it would have been impossible to demonstrate the true scope of that system, or that the "arc cloud" penetrated by the aircraft at $150 \mathrm{~m}$ was indeed a remnant gust front from a large squall line, a mesoscale convective system that had initiated the previous evening. Later, with the experience gained in Barbados in 1968, more complete and accurate descriptions of tropical squall lines became possible (Seguin and Garstang 1976; Zipser 1977; Houze 1977).

Based on the idea of importance of mesoscale systems, and their interactions with other scales of motion, the LIE data were designed to cover as much of the subsynoptic scales in space and time as possible. Soundings from the islands and the R/V Surveyor (Zipser 1970) were obtained at 6-h and, on many days, 3-hourly intervals, and processed to reveal finescale structures in the vertical, exploited by Madden and Zipser (1970) as a manifestation of a type of equatorial wave predicted by Lindzen and Matsuno (1968). The few examples of mesoscale systems in the form of squall lines, observed during the LIE were of obvious scale-interaction importance, but it remained for the Barbados (1968) and especially the GATE (1974) experiments to cement and quantify their role and to stimulate decades of future work in improving parameterization of convection. It is fair to admit, however, that even today weather and climate models struggle to simulate mesoscale convective processes without bias.

\section{THE I968 FLORIDA STATE UNIVERSITY BARBADOS EXPERIMENT. During the summer} of 1968, personnel, ranging from senior scientists to newly minted graduates, descended upon the island of Barbados. For the latter group, it was their first exposure to field work and data collection, and many used it as a springboard for future work in tropical meteorology. The educational environment of the 1960s was markedly different than it is today, particularly with regard to research opportunities for college students. Current experimental programs, such as Research in Undergraduate Institutions (RUI), did not exist, and the opportunity to be mentored by and work together with seasoned scientists was indeed a life-changing experience for a group of novice researchers. In early June, as the C-124 cargo aircraft lumbered down the Tallahassee runway, many of us could not help but view this undertaking as the "Barbados adventure." 
As with the LIE, the 1968 Barbados Experiment was designed to sample a spectrum of temporal and spatial scales of motion. Central to these processes are the exchanges of heat, mass, and momentum that begin at the air-sea interface and progress through discrete layers of the atmosphere, occasionally penetrating the tropopause at over $15 \mathrm{~km}$. These interacting scales of motion are grounded in the observed interdependence of tropical weather systems. No squall line exists over the open tropical ocean that is not dependent upon deep convective clouds and no hurricane exists without highly organized convection in the form of spiral bands and the eyewall of the storm. Each of these component parts of the storm are coupled to the sea surface such that decreases in sea surface temperature or passage over land will disrupt or even dissipate the system (Malkus 1962; Garstang and LaSeur 1968; Garstang et al. 1970). (See the "Field work in foreign places" sidebar.)

Two objectives of the 1968 experiment influenced subsequent field research and understanding:

1) the reliability and role of the fluxes of latent and sensible heat between the sea surface and the deeper atmosphere and

2) the coupling of the boundary layer and the convective cloud layer.

To achieve these objectives, a linear configuration of observing stations was chosen for the experiment, extending along $13^{\circ}$ latitude from $25 \mathrm{~km}$ west to $125 \mathrm{~km}$ east (Fig. 1). The deployment allowed measurements to be compared and contrasted along an east to west line, over intervening fixed stations, sampling contrasting land and ocean surfaces. On land, three $16-\mathrm{m}$ towers were deployed along this transect. The towers were equipped with multilevels of instrumentation and could be periodically lowered for servicing and calibration of instruments. The three sites also consisted of data-recording systems, housed in small trailers and were manned continuously to ensure data consistency and reliability. (See the "Barbados" sidebar.)

Additional support was provided by two aircraft (NCAR Queen Air and Weather Science, Inc., Twin Cessna), which performed longitudinal and circumisland measurements. Also, the U.S. Navy and Air Force provided weather reconnaissance flights over a wider area east and north of the experiment array.

The fluxes of heat and moisture were determined from measurements taken on a specially designed spar buoy and from the R/V Discoverer. Ships and buoys present a number of problems in ocean waters

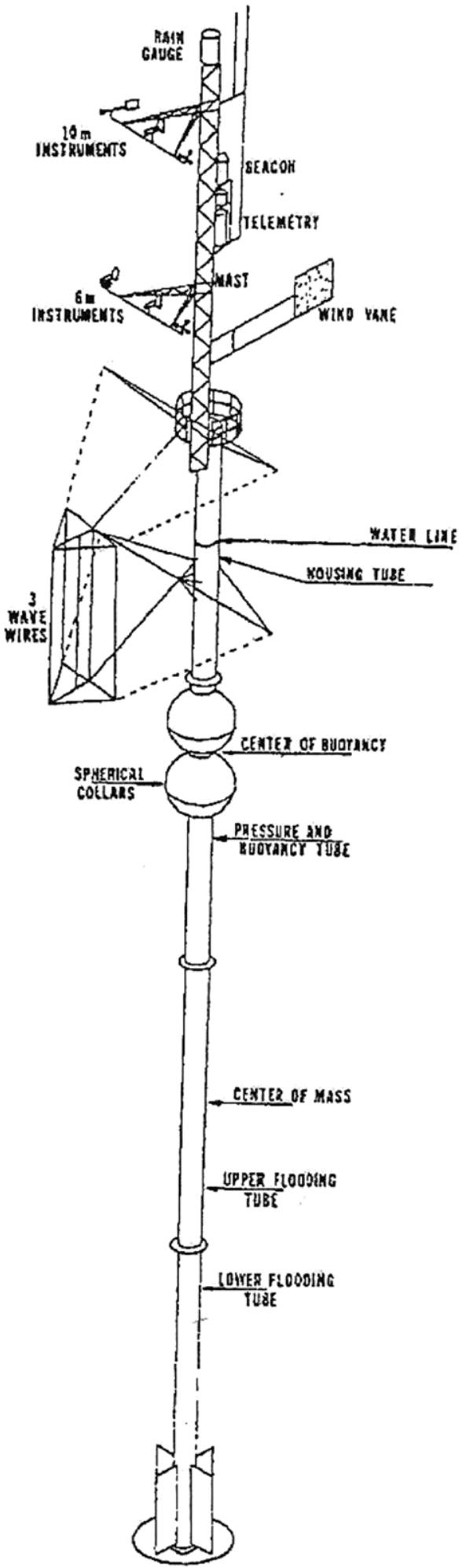

Fig. 2. Triton buoy carried instrumentation to determine the exchange of heat, water vapor, and momentum between the ocean surface and the overlying atmosphere, as well as ocean wave heights, period, speed, direction, and spectra and the accelerations, inclination, and orientation of the buoy (after Warsh et al. 1970). 
deeper than a few tens of meters. Anchoring of a large research ship is not feasible and even an anchored buoy moves over an area of ocean as much as a square kilometer. For its part, a ship presents an unstable obstacle to the winds being measured and a heat source that affects the measurement of temperature and humidity. In addition, radio and other transmissions on the confined space of a ship can interfere with data feeds on board.

Triton. A 34-m spar buoy, Triton (Fig. 2), was designed and constructed for the 1968/69 experiments (Warsh et al. 1970; Warsh and Garstang 1970).

Triton (Fig. 3) served as a reliable platform over a range of sea states; however, severely disturbed weather (winds above $20 \mathrm{~m} \mathrm{~s}^{-1}$ ) were not encountered and the threshold beyond which measurements became unreliable was not determined (Warsh and Garstang 1970; Persson et al. 2005; Yang et al. 2014; Potter et al. 2015). (See "The manure pile" sidebar.)

The bulk aerodynamic equations were used to calculate the heat and momentum fluxes from the hourly averages of the required variables shown in Fig. 4. Momentum fluxes were estimated using a drag coefficient following Deacon and Webb (1962), based on the mean hourly horizontal wind. With quantities averaged over $1 \mathrm{~h}$, none of the platform motions measured on Triton were found to influence these heat flux estimates. Results are shown for five days in August 1968 (Fig. 4). Significant increases in both latent and sensible heat are recorded during the passage of a weak synoptic-scale system near midnight on 20 August (Garstang and Warsh 1970; Warsh et al. 1972b).

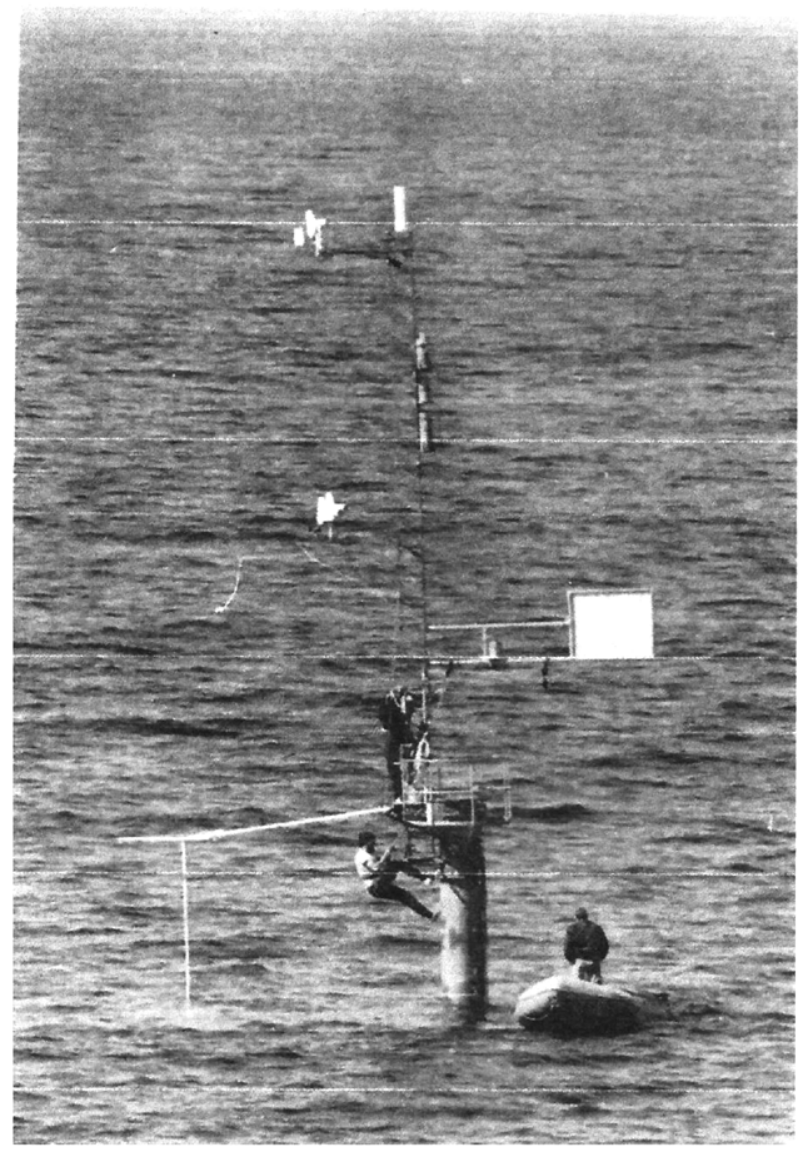

Fig. 3. Triton deployment on station $24 \mathrm{~km}$ due east of East Point lighthouse, Barbados, in 1968 (Florida State University 1968 experiment Archives).

\section{THE MANURE PILE}

The 1968 Florida State University Barbados Meteorological Experiment placed particular emphasis upon the calibration of instruments in the field. A full-scale wind tunnel was among these tools. The cylindrical steel section containing the power train tipped the scales at a few hundred pounds. At Seawell Airport this heavy section was unloaded from the Georgia National Guard C-I24 aircraft onto a truck by an airport forklift. At the Caribbean Meteorological Institute, no such mechanical help was available. Horses were still stabled at the institute and there was a 5-6-ft-high pile of fresh horse manure. It took no effort to roll the motordrive section off the truck and drop it onto the cushioning pile of manure. Hosed down and rolled into the shed the task was done.

FIG. SB3. Wind tunnel to calibrate anemometers in the field (Florida State University 1968 experiment photographic archives).

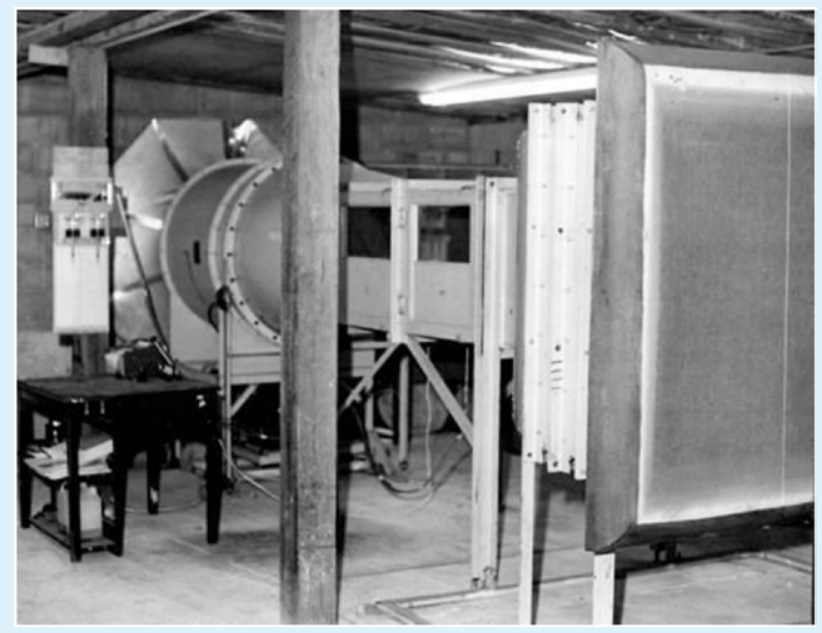




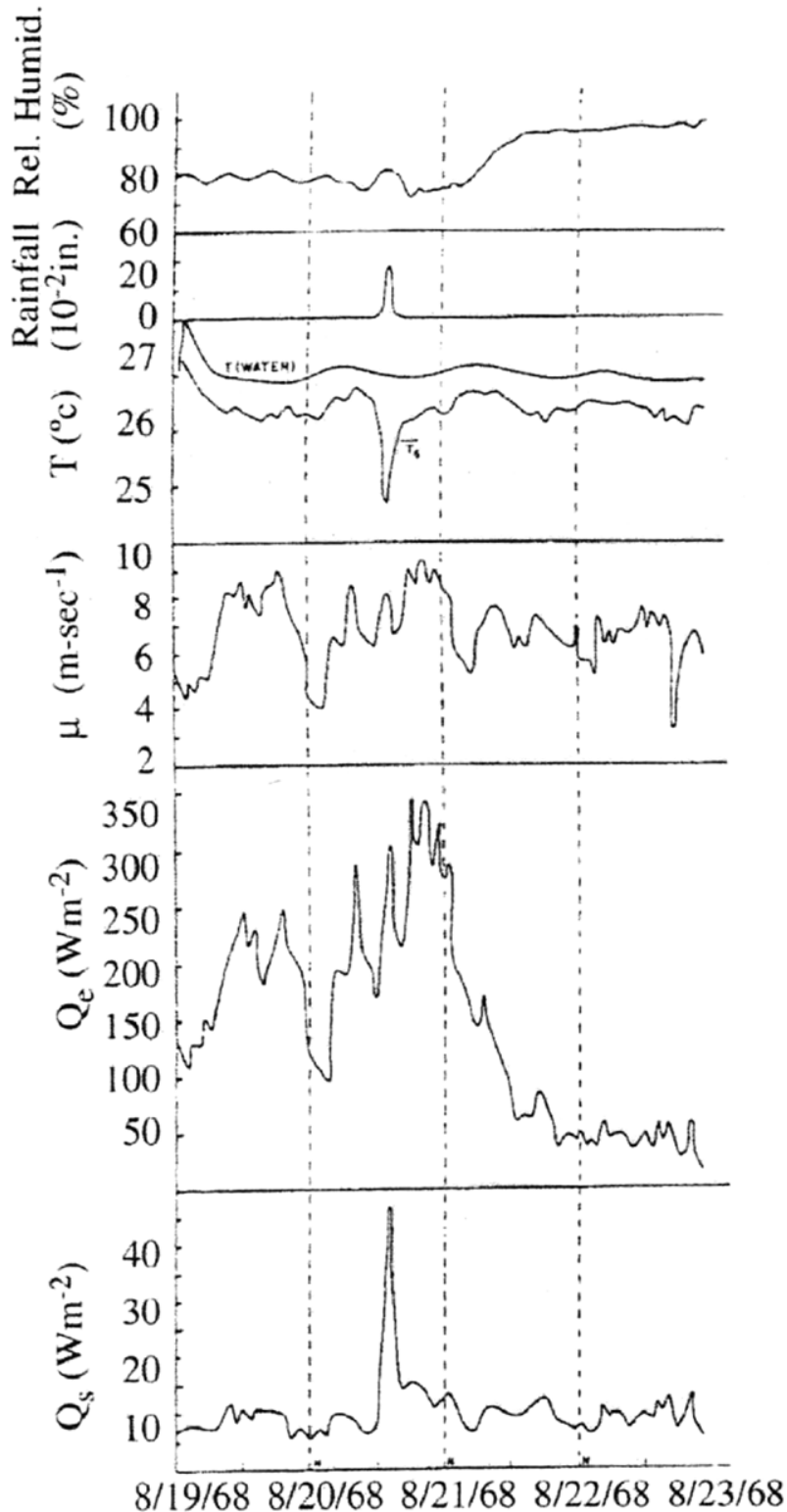

Fig. 4. Triton buoy measurement and latent heat flux $\theta_{e}$ and sensible heat flux $\theta_{s}, 23$ Aug $196824 \mathrm{~km}$ east of Barbados in cal $\mathrm{cm}^{-2}$ day $^{-1}$ (after Garstang and Warsh 1970).

The stability of Triton together with the array of resistance wave staffs, pressure transducer, accelerometers, and inclinometers permitted wave spectra to be calculated (Grose et al. 1972a,b; Warsh et al. 1972a). These measurements coupled with airflow and ocean currents anticipated the importance of interaction between the surface airflow and ocean waves (Smith 1980; Fairall et al. 1996).

R/V Discoverer. A retractable boom system was mounted on the bow of the R/V Discoverer extending $10 \mathrm{~m}$ forward of the vessel and $10 \mathrm{~m}$ above the mean

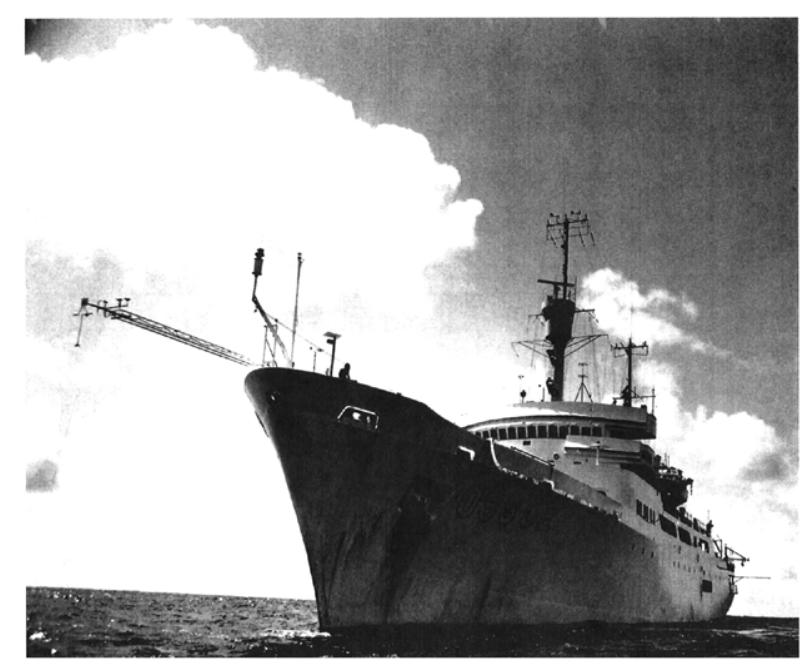

FIG. 5. Retractable instrument boom system on R/V Discoverer 1968 and 1969 with temperature and relative humidity in circular radiation shields, wind speed and direction, and radiometers $10 \mathrm{~m}$ above sea surface. Line to sea surface temperature probe seen extending forward to sea surface with rain gauge on forward slanting arm and propeller vane anemometers on forward masthead (Florida State University 1968 experiment archives).

sea surface. Cup anemometers with wind direction vanes, shielded wet- and dry-bulb thermistors, and radiometers were mounted on the end of the boom. Additional propeller vane anemometers were mounted at an approximately $20-\mathrm{m}$ height on the forward masthead of the ship (Fig. 5). Sea surface temperature was measured by a float mounted thermistor suspended just below the sea surface at the head of the forward boom (Warsh et al. 1972b). Analog systems recorded data at 15-min intervals from which hourly average fluxes of latent and sensible heat and momentum were calculated using a wind-dependent drag coefficient (Deacon and Webb 1962).

Comparison between estimates of air-sea fluxes of heat, water vapor, and momentum based on measurements taken onboard the R/V Discoverer and Triton showed that common shipboard errors of $1^{\circ}-2^{\circ} \mathrm{C}$ resulted in sensible heat flux differences of $100 \%-300 \%$ at $6 \mathrm{~m} \mathrm{~s}^{-1}$ wind speeds between the ship and buoy. At only slightly higher wind speeds, a $1^{\circ} \mathrm{C}$ shipboard error in air-sea temperature difference yields an order of magnitude error in sensible heat flux. Latent heat flux shipboard measurements are shown to be even more difficult to assess. Such errors were greater than 30\% (Seguin and Garstang 1971).

Significant progress has been made in dealing with high wind speeds and rough seas. Surface roughness with adjustments made to the drag coefficient, have 
D espite the small size of Barbados, one soon leaves the lights of Bridgetown and the sights of the west coast. Two of our three main instrument sites, East Point and Cottage, were quite remote. We recruited the local landowner to watch over the site. This was as much to involve him as a participant and hence as an ally. We soon found that Barbadians take their responsibilities seriously.

At East Point, the owner expressed concern that we intended trespassing on the Lord's domain by flying the tethered balloon. We were at a loss as to how to deal with his conviction. The solution, however, was unexpected. When we paid him his first two weeks rent and wages, he rewarded his neighbors by buying them rum from the ubiquitous local rum shop. As LaSeur, with the balloon overhead, led the parade of locals plus all of the neighborhood's children to the launch site, the owner took the lead proclaiming loudly, "Hallelujah, let it go! Hallelujah, let it go!"

We never found the boundary separating us from the Lord's domain.

At Cottage we were puzzled that no nocturnal rainfall was recorded. We asked the night watchman whether it had rained at night. "Oh yes sir, plenty rain at night," was the

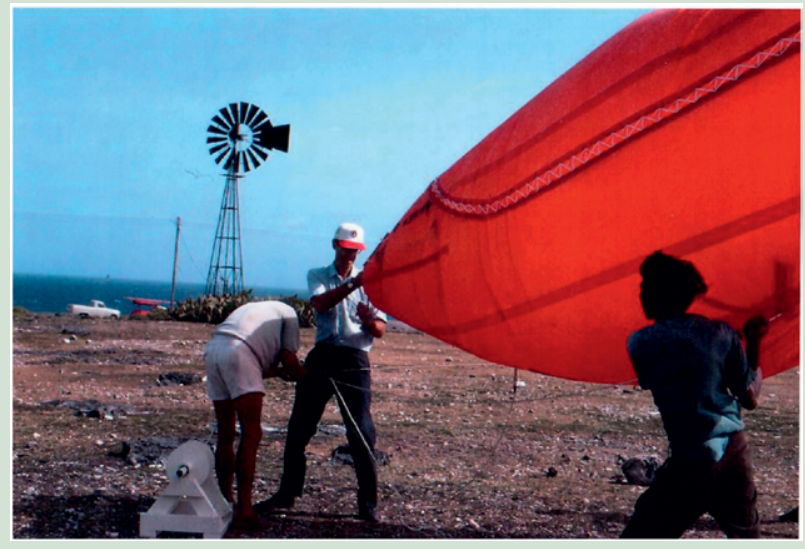

Fig. SB4. Preparing to launch the tethered balloon: Prof. Noel LaSeur (with cap), and graduate students (left) Carl Aspliden and (right) John Lee (Florida State University 1968 experiment photographic archives).

reply. "Oh really, how come none was recorded?" "Oh sir, this beautiful instrument, I do not wish it to get wet! I put in the shed each evening and take it out in the morning!" been applied under wind speeds up to $25 \mathrm{~m} \mathrm{~s}^{-1}$ (Edson et al. 2013; Fairall et al. 1996, 2003; Smith 1980). Shipboard measurements in the maritime tropics are, however, subject to low wind speeds $\left(<10 \mathrm{~m} \mathrm{~s}^{-1}\right)$ that amplify errors in temperature, humidity, and wind speed. In contrast, shipboard measurements at higher latitudes are taken often under much higher wind speeds and much larger range in air-sea differences than in the tropics (Persson et al. 2005; Yang et al. 2014).

Tethered balloon and aircraft investigation of cloudlayer-subcloud-layer interactions. While the uniqueness of the Barbados Experiment rests upon its focus on the tropical ocean, it was hardly the first to recognize the interaction of downdrafts from precipitating convective clouds with their subcloud-layer environment for initiating new, often stronger convective clouds. The Thunderstorm Project (Byers and Braham 1949) broke new ground with a combination of multiaircraft penetrations of deep convection together with closely spaced surface observations in Florida (1946) and Ohio (1947). Newton (1950) was among the first to use these data to describe squall lines over the United States. But the 1968 Barbados Experiment pioneered the development and effective use of new technology to investigate these interactions over tropical oceans. (See the "Barbadian support" sidebar.)
A tethered balloon system had been pioneered in Barbados in 1963 using a British Meteorological Office tethered sonde. Analog recording limited the use of this sonde such that a new telemetry and digital recording sonde was developed for the 1968 experiment. The 1968 tethered sonde and associated telemetry and recording system (Fig. 6), were capable of recording simultaneous time series of meteorological variables at four levels. Analysis suggested that turbulent mixing in the boundary layer is governed by moist plumes on the scale of $100 \mathrm{~m}$ or more. Warner and Telford (1963) and Telford and Warner (1964), measuring temperature fluctuations in the subcloud layer by aircraft, concluded that thermals play an important role in the vertical transfer of energy. In the 1968 experiment, the fluctuations detected by nearly fixed-level tethered balloon sensors were more evident in the humidity rather than the temperature field. The observed fluctuations in humidity depended both upon vertical and horizontal displacement of subcloud air (Garstang et al. 1971).

Significant success in observing cloud initiated downdrafts, however, was later achieved using a dense network of surface $(8 \mathrm{~m})$ anemometers and rain gauges in the Florida Everglades Area Cumulus Experiments (FACE) of 1971 and 1973 to calculate velocity divergence preceding large convective storms. This leading convergence generated from 
the storm outflow preceded the rain by as much as 90 min (Fig. 7) (Ulanski and Garstang 1978a,b,c; Cooper et al. 1982).

Between 1968 and 1974, pioneering work was done on tethered balloons including tether line (the introduction of Kevlar), specially designed heavyduty hydraulic winches (tension release devices, level-wind capability, and speed control), together with greatly improved sondes (reporting vertical velocity, stability, cloud entry and exit), and multilevel and channel digital recording and transmission. This work was carried out at the University of Wisconsin-Madison, Florida State University, and the University of Virginia.

During GATE, these sondes made measurements at five levels below convective cloud base and at a sixth in-cloud level signaling entering and exiting the convective cloud. Transmission from all six sondes was simultaneous (Fig. 8) (Emmitt 1978).

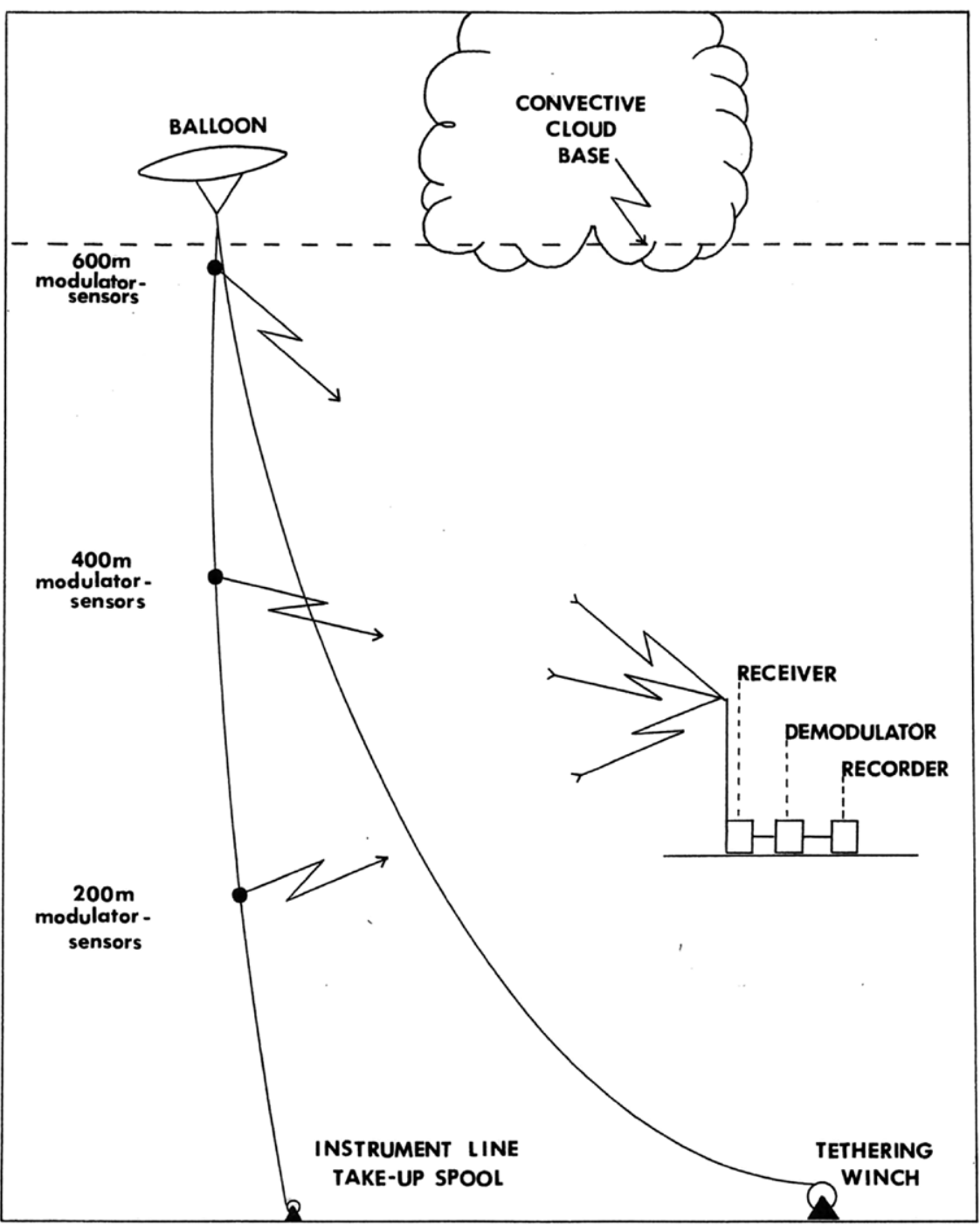

Fig. 6. Land deployment of tethered balloon in 1968. Ship deployment suspended instruments from the tether line. Three out of four instrument levels shown (after Garstang et al. 1968).

These measurements, in an Eulerian framework, provide valuable documentation of the time continuity and characteristics of cloud outflows previously sampled by aircraft and simulated by cloud models.

During GATE, horizontal layers up to $10 \mathrm{~km}$ long and ranging in thickness from 300 to $600 \mathrm{~m}$ were shown to exist in the fair weather boundary layer. While these bands differed in potential temperature and specific humidity from each other, they were individually uniform in these variables (Barnes et al. 1980). The consequences of making these tethered balloon observations will be revisited in the closing section of this paper.

In 1968, aircraft flights in the presence of nonprecipitating cumulus clouds showed that weak but significant coupling exists between the cloud and subcloud

layer in cloud-free regions (Seguin and Garstang 1976). Compensating sinking in these cloud-free spaces maintains mass balance in the whole cloud and cloud-free volume. The downward transfer of sensible heat warms the subcloud layer from above stabilizing the intercloud regions within cloud fields. These processes, under disturbed conditions, make the determination of energy budgets increasingly difficult (Echternacht and Garstang 1976). Following on from this work in GATE, Barnes and Garstang (1982), together with Fitzjarrald and Garstang (1981a,b), suggested that precipitating convection occurring in a weakly disturbed environment, by bringing cooler air in contact with the warm ocean surface, results in $60 \%$ greater transfer of energy per unit mass than convective clouds achieve operating in an unmodified 


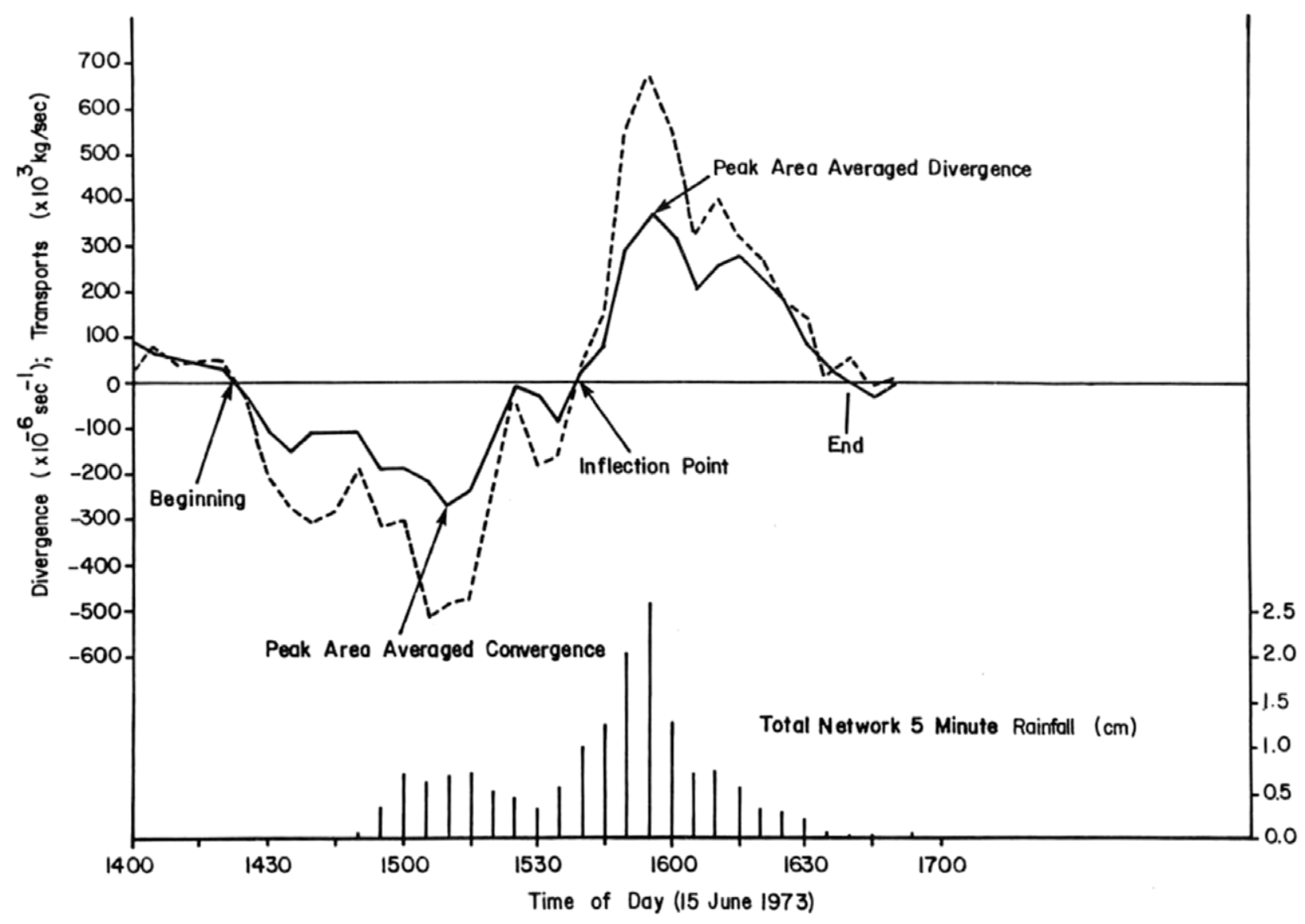

Fig. 7. Time changes through a "wet" day, 15 Jun 1973, of the network averaged divergence (solid) and resulting mass transports (dashed), calculated from the surface $(8 \mathrm{~m}$ ) wind observations (after Cooper et al. 1982).

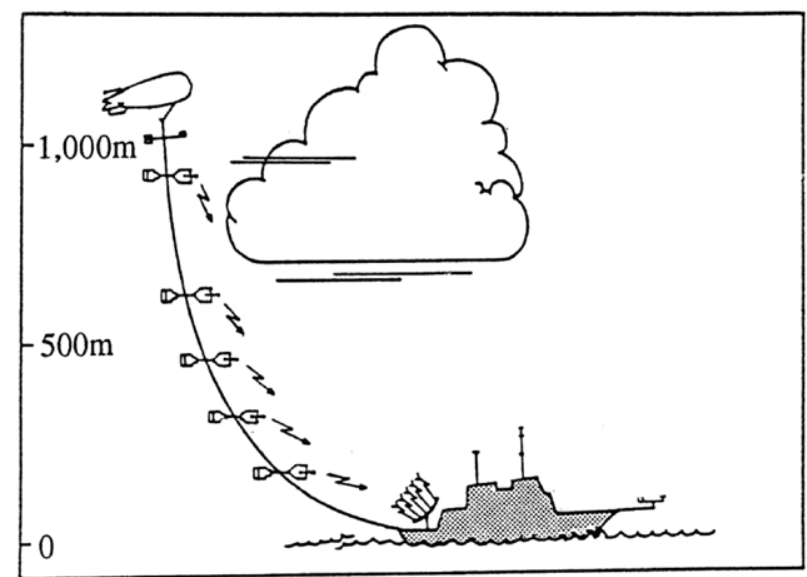

FIG. 8. Tethered balloon system as used in GATE 1974. Five sondes measuring temperature, specific humidity, horizontal and vertical winds together with an upper sonde recording cloud entry and exit, simultaneously transmitted to digital recording and analog display onboard ship (after Emmitt 1978). region, reversing the process occurring in the nonprecipitating state described above. This identification of the consequences of the "convective wake" region on surface exchanges was later confirmed using the same analysis with data from the TOGA COARE project (e.g., Johnson et al. 2001).

The NCAR Queen Air made 92 research flights during the 1968 experiment and 76 flights in 1969 BOMEX. During 1968, many of these flights supplemented the boundary layer measurements by the towers, buoys, and tethered balloons by flying long legs upwind, over, and downwind of Barbados, often at $150-\mathrm{m}$ altitude above the surface. In addition, as "targets of opportunity" arose, the aircraft penetrated convective clouds and occasionally squall lines (Seguin and Garstang 1976; Zipser 1977). The lessons learned during these flights led directly to the design of the aircraft program during GATE, when 13 aircraft participated in hundreds of successful missions focused on boundary layer, convection, and radiation objectives. Not least of those lessons was that safe operation of research aircraft at these altitudes over tropical oceans, even in deep convection, was 


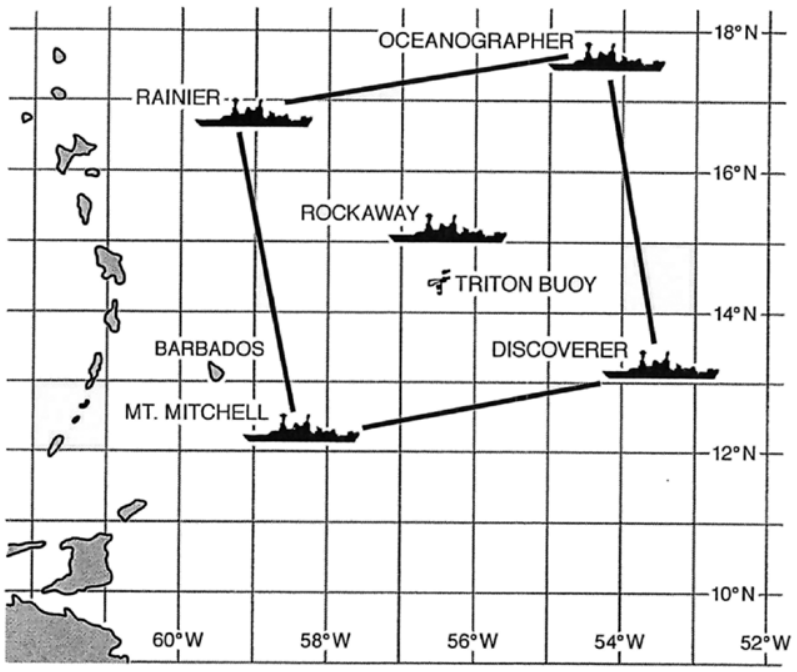

FIG. 9. Ship array during 1969 BOMEX; position of Triton approximate (modified after Holland and Rasmussen 1973).

not only possible, but essential for obtaining data in both subcloud and cloud layers. Only in GATE were resources sufficient to obtain the statistical information on typical strength and properties of tropical oceanic convection at many altitudes (LeMone and Zipser 1980; Zipser and LeMone 1980).

THE BOMEX 1969. The primary objective of the 1969 BOMEX was to determine the rate of transfer of water vapor, heat, and momentum from the tropical ocean to the atmosphere. A $500-\mathrm{km}$ square ship array was laid out some $200 \mathrm{~km}$ east of the Windward Islands between the latitudes of $12^{\circ}$ and $18^{\circ}$ north. A single ship, the Coast Guard Cutter Rockaway, was stationed in the middle of the 4 ship array (Fig. 9). Research aircraft were used, together with the U.S. Navy's Floating Laboratory Instrument Platform (FLIP) and the Florida State University spar buoy Triton (Holland and Rasmussen 1973).

This 5-day undisturbed period was mostly shallow cumulus. Rain amounts over Barbados were less than $0.2 \mathrm{~mm}$ day $^{-1}$. Fifteen rawinsondes were released on each of the five consecutive days during an intensive observation period, with most reaching $500 \mathrm{mb}$ $(6 \mathrm{~km})$. Computations of divergence and vertical velocity were made every $10 \mathrm{mb}$.

Figure 10 shows the divergence from the surface to $500 \mathrm{mb}$ above the surface in units of $10^{-5} \mathrm{~s}^{-1}$ and vertical velocity in $p$ coordinates. Three estimates of divergence, measured by research aircraft, one daylight and two $10 \mathrm{~h}$ nocturnal missions, are marked on Fig. 10. The aircraft estimates of divergence were obtained from measuring the wind components

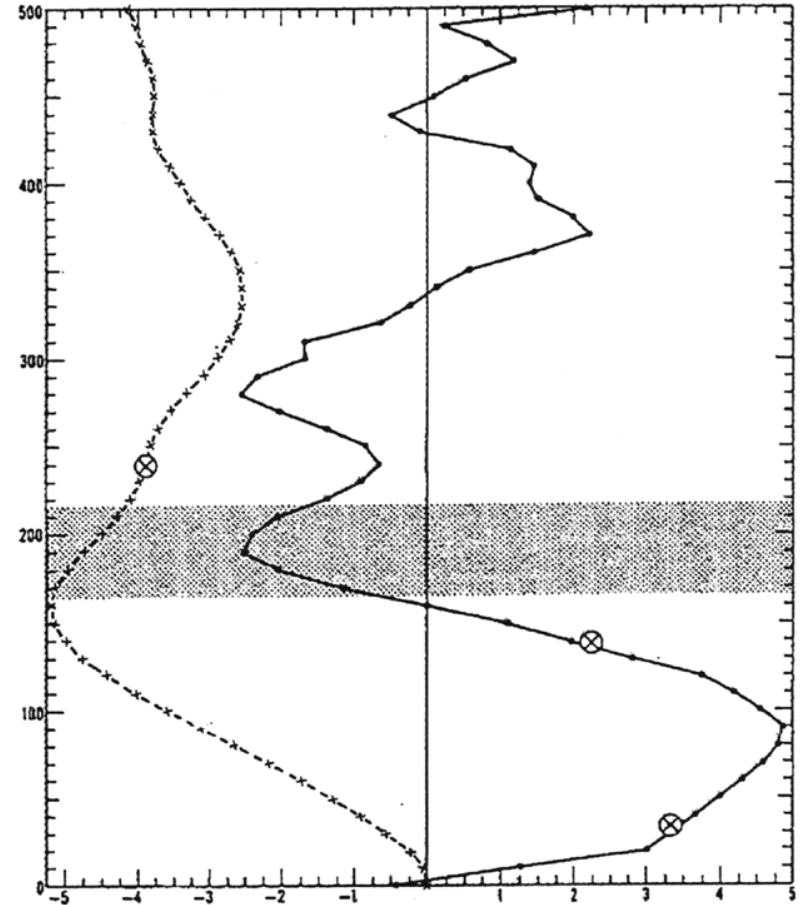

FIG. 10. Vertical profiles of horizontal velocity divergence in units of $10^{-5} \mathrm{~s}^{-1}$ on the abscissa (solid) and the pressure differential relative to sea level in millibars on the ordinate (cross-dash). The crossed circles are average horizontal divergence from aircraft measurements (modified after Holland and Rasmussen 1973).

parallel and normal to the eastern and western walls of the box (Holland 1971). It is surprising that these estimates are in almost exact agreement to the 5-day mean values obtained from the rawinsoundings. Maximum divergence $\left(4.5-5.0 \times 10^{-5} \mathrm{~s}^{-1}\right)$ is found at $80 \mathrm{mb}$ above the surface, the level of maximum wind. Zero divergence and maximum downward motion is found at the base of the stable layer at $160 \mathrm{mb}$ above the surface commonly referred to as the trade wind inversion. The computed values of divergence and vertical velocity show greater variability with height above the inversion.

Table 1 (Holland and Rasmussen 1973) shows the individual terms of the water vapor budget as derived from the budget calculation. The water balance (evaporation) is a result of the downward advection of dry air from the subtropical anticyclone and upward transport from the sea surface, consistent with Riehl et al. (1951). Their estimated evaporation, however, may be overestimated by about $20 \%$. Table 2 (Holland and Rasmussen 1973) shows the sea-air fluxes from the budget calculations for the remaining quantities.

Colon (1960), and subsequently a number of others, notably Johnson, have made budget calculations for larger and smaller volumes. Obtaining estimates of 


\begin{tabular}{|lc|}
\hline \multicolumn{2}{|l|}{ TABLE I. Average water balance } \\
\multicolumn{2}{|l|}{ components (modified after } \\
Holland and Rasmussen & 1973). \\
\hline Component & mm day $^{-1}$ \\
Local change & +0.5 \\
Mean divergence & +5.7 \\
Horizontal advection & +0.6 \\
Flux through the top & -1.0 \\
Precipitation & +0.2 \\
Evaporation & 6.0 \\
\hline
\end{tabular}

fluxes over such large areas as the Caribbean provide insight into the potential net effects of the large-scale circulations, opening this approach for those to come.

Estimates of budgets over much smaller areas at and below the volume considered in BOMEX, encounter sampling difficulties particularly under conditions of increasing convection and precipitation. Wind profiles extending to higher levels are, in particular, subject to large but real variability. Although dropwindsondes from aircraft have improved markedly, spatial and temporal definition of the wind fields remains a problem, especially in the presence of convective clouds and precipitation.

The progressive improvement of Doppler wind lidar (DWL) systems, however, promises the ability to determine a clearer picture of the wind field through the depth of the tropical troposphere over the open oceans by aircraft and ultimately by satellites (Emmitt

\begin{tabular}{|c|c|}
\hline & 5-day mean \\
\hline Water vapor (mm day-1) & 6.0 \\
\hline Latent heat (cal m ${ }^{-2}$ day $^{-1}$ ) & $249 \times 10^{4}$ \\
\hline Sensible heat (cal $\mathrm{m}^{-2}$ day $^{-1}$ ) & $30 \times 10^{4}$ \\
\hline Momentum ( $\mathrm{N} \mathrm{m}^{-2}$ ) & -0.065 \\
\hline
\end{tabular}

et al. 2019). While the lidars are dependent upon the presence of aerosols and the absence of closed cloud conditions, the results of the 2017 Convective Precipitation Experiment (CPEX) over parts of the Gulf of Mexico, the Bahamas east of Florida, and the Caribbean Sea are encouraging (Greco et al. 2019). Figure 11 shows a comparison of all wind measurements between the dropwindsonde and the DWL in CPEX. Rigorous quality control tests have been carried out on the CPEX 2017 Doppler wind data including tests for bias in wind speed and direction (Emmitt et al. 2019). Table 3 shows that the bias in wind speed is less than $0.70 \mathrm{~m} \mathrm{~s}^{-1}$ and wind direction less than $2.2^{\circ}$.

Using Doppler Aerosol Wind (DAWN) lidar wind profile measurements, divergence was calculated for the middle and lower troposphere in two collocated volumes of undisturbed conditions (no precipitating convection) during CPEX (Fig. 12). The size of each vol-
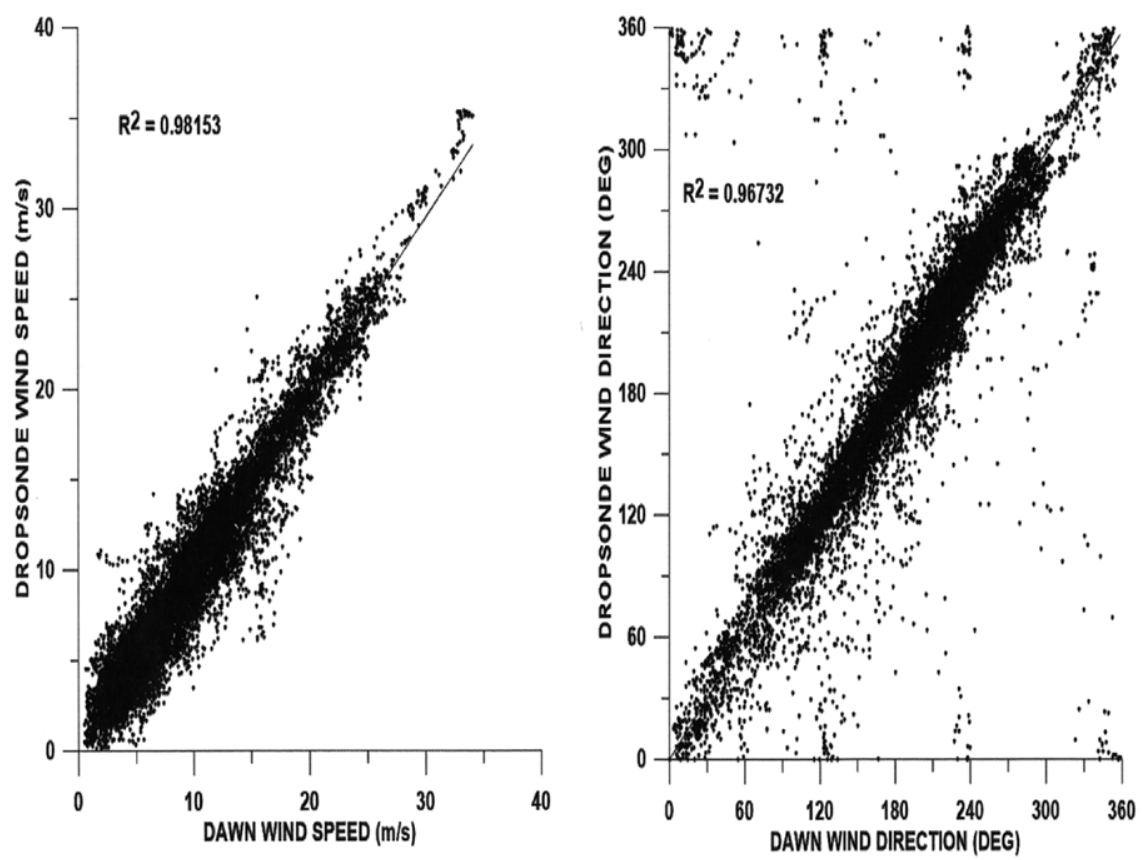

FIG. II. CPEX dropwindsonde comparison with Doppler wind lidar (DWL) wind speed and direction measurements (after Greco et al. 2019). ume, flown one hour apart, was $110 \mathrm{~km} \times 110 \mathrm{~km} \times 7 \mathrm{~km}$ with wind profiles from the DWL provided every $5 \mathrm{~km}$ over the $\sim 48 \mathrm{~min}$ it took to fly the volume. The magnitude of the divergence of $4 \times 10^{-5}$ and $5 \times 10^{-5} \mathrm{~s}^{-1}$ for both volumes is well within the range expected over the tropical ocean under undisturbed conditions. The vertical distribution of the divergence is similar in both volumes and the magnitude of vertical distribution is compatible with shallow trade wind cumulus with cloud base at about $700 \mathrm{~m}$ and cloud tops below $3,000 \mathrm{~m}$. Work on progressively disturbed cases will provide the opportunity to 
TABLE 3. Comparison biases and random differences in CPEX 2017 (after Greco et al. 2019). RMSD = root-mean-square difference.

\begin{tabular}{|lccccc|}
\hline Date & $\begin{array}{c}\text { No. of } \\
\text { comparisons }\end{array}$ & $\begin{array}{c}\text { Wind speed } \\
\text { bias }\left(\mathbf{m ~ s}^{-1}\right)\end{array}$ & $\begin{array}{c}\text { Wind speed } \\
\text { RMSD }\left(\mathbf{m ~ s}^{-1}\right)\end{array}$ & $\begin{array}{c}\text { Wind direction } \\
\text { bias }\left(^{\circ}\right)\end{array}$ & $\begin{array}{c}\text { Wind direction } \\
\text { RMSD }\left(^{\circ}\right)\end{array}$ \\
$\begin{array}{l}\text { 3I May and } \\
\text { II Jun 2017 }\end{array}$ & 2,174 & 0.68 & 1.83 & +2.11 & 6.9 \\
\hline
\end{tabular}

examine the scale interactions between convection and the velocity field.

DISCUSSION AND CONCLUSIONS. The preceding description of component parts of the three field experiments was directed at extending the understanding of the behavior of the atmosphere over the large reaches of the low-latitude oceans. In the Line Islands Experiment this consisted of establishing "ground truth" for the "giant leap forward" provided by the geosynchronous satellite, for the Florida State University (FSU) Barbados Experiment more precise and detailed measurements of the air-sea interface and the subcloud-cloud-layer interaction and for BOMEX an initial estimate of the budgets of heat, water vapor and momentum over the open ocean.

Central to these field programs was the realization that widely different scales of motion are often interacting over tropical oceans. The geosynchronous

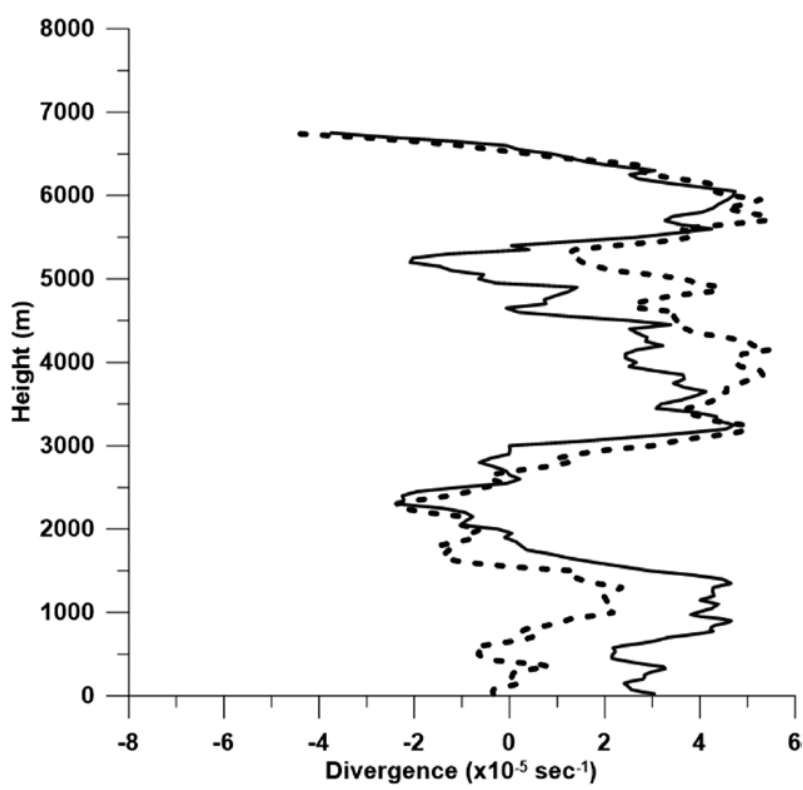

Fig. 12. Velocity divergence results derived from Doppler wind lidar airborne measurements taken along the sides of a $110 \mathrm{~km} \times 110 \mathrm{~km}$ box between the sea surface and $7 \mathrm{~km}$ during undisturbed (nonprecipitating cumulus) conditions. Duration of flight $48 \mathrm{~min}$. Soundings every $5 \mathrm{~km}$. Solid line box B, dashed line box A (after Greco et al. 2019). satellite provided the first comprehensive observations of the tropics-wide cloud field, from the subtropical highs through trade wind belts to the equatorial trough zone. The subtropical anticyclones exert perhaps the strongest control on the largest areas through their large-scale subsidence, suppressing even trade cumuli near their centers, but as subsidence is relaxed (or even eliminated) in the downstream reaches of the trade winds, or closer to the equatorial zone, precipitating convection with stronger outflows, and mesoscale disturbances become of vital importance as they interact with synoptic-scale systems.

Triton was designed to minimize the negative effects on the exchange of heat, water vapor, and momentum measured from large unstable platforms in the deep tropical ocean. Of particular concern was the effect of a large platform such as a ship on the wind field, as a heat source on temperature and water vapor and as an unstable platform affecting the motion field measurements in the air and water. Although no absolute standard exists for the measurement of these quantities, confidence in the results was improved.

Significant day-to-day fluctuations in the exchange of latent and sensible heat between the sea surface and the atmosphere was recorded by the Triton buoy. Under undisturbed fair weather, both heat sources are low. Under a weak weather system, there is a substantial increase in latent and sensible heat exchange. Exchanges can be significantly higher under more intense systems.

Evidence, not well consolidated in the findings of these experiments, suggests, however, that these large storm-based fluxes of sensible and latent heat are a result rather than a cause of more intense convection and rainfall. They remain as a necessary but not sufficient condition to the maintenance of the systems. Once boundary layer growth penetrates the lifting condensation level, sensible and latent heat support the growth of trade wind cumulus. The tethered balloon sonde measurements obtained in GATE provided direct evidence of the cloud outflows and the subsequent entrainment of fresh boundary layer air.

Estimates of divergence and vertical velocity derived from averaging multiple soundings from an 
array of four ships separated by $500 \mathrm{~km}$ over five days as carried out in BOMEX show persistent downward motion over a volume that extends to $500 \mathrm{mb}(\sim 6 \mathrm{~km})$. High-resolution spatial and temporal measurements of horizontal winds using airborne DWL provide an opportunity to further understand the interaction between the velocity field and convection. The three tropical experiments, conducted a half century ago, left a visible footprint over the subsequent time span. Much of what was attempted awaited future culmination but with a growing promise of robust solutions.

ACKNOWLEDGMENTS. Faculty of the then Department of Meteorology and Oceanography at Florida State University, in particular, Professor Noel LaSeur (deceased) to whom this paper is dedicated, supported this work from its inception to well beyond its field phase. Woods Hole Oceanographic Institution and Dr. Joanne Simpson (deceased) both participated and supported the experiment together with the administration of both institutions.

We also wish to recognize and thank Dr. Gene Bierly, National Science Foundation, Mr. Marvin Lowenthal (deceased), Army Research Office, and Feodor Ostapoff (deceased) of the Air-Sea Interaction Laboratory of the National Weather Service, and with great nostalgia, Mr. David Smedley (deceased), Mr. Geoffrey Rudder of the Caribbean Meteorological Institute, and the government and people of Barbados.

We are indebted to Mary Morris for all of her archival work and for the preparation and submission of this manuscript.

We wish to thank Florida State University, the University of Virginia, the University of Utah, Simpson Weather Associates, Inc., and the American Meteorological Society's publication office, all of whom contributed substantially to the cost of publication of this article. Equally, we are indebted to and thank the editorial staff of $B A M S$ and the guidance of the reviewers of the paper.

\section{REFERENCES}

Barnes, G. M., and M. Garstang, 1982: Subcloud layer energetic of precipitating convection. Mon. Wea. Rev., 110, 102-117, https://doi.org/10.1175/1520-0493 (1982) $110<0102:$ SLEOPC $>2.0 . C O ; 2$.

-, G. D. Emmitt, B. Brummer, M. A. LeMone, and S. Nicholls, 1980: The structure of a fair weather boundary layer based on the results of several measurement strategies. Mon. Wea. Rev., 108, 349-364, https://doi.org/10.1175/1520-0493(1980)108<0349:TS OAFW>2.0.CO;2.

Byers, H. R., and R. R. Braham Jr., 1949: The Thunderstorm. U.S. Government Printing Office, 287 pp.
Colon, J. A., 1960: On the heat balance of the troposphere and water-body of the Caribbean Sea. National Hurricane Research Project Rep. 41, 65 pp.

Cooper, H. J., M. Garstang, and J. Simpson, 1982: The diurnal interaction between convection and peninsular scale forcing over south Florida. Mon. Wea. Rev., 110, 486-503, https://doi.org/10.1175/1520-0493 (1982) $110<0486$ :TDIBCA $>2.0 . C O ; 2$.

Deacon, E. L., and E. K. Webb, 1962: Interchange of properties between the sea and air. Physical Oceanography, M. N. Hill, Ed., The Sea-Ideas and Observations on Progress in the Study of the Seas, Vol. 1, John Wiley and Sons, 43-87.

Echternacht, K. L., and M. Garstang, 1976: Changes in the structure of the tropical subcloud layer from the undisturbed to disturbed states. Mon. Wea. Rev., 104, 407-417, https://doi.org/10.1175/1520-0493 (1976)104<0407:CITSOT>2.0.CO;2.

Edson, J. B., and Coauthors, 2013: On the exchange of momentum over the open ocean. J. Phys. Oceanogr., 43, 1589-1610, https://doi.org/10.1175/JPO -D-12-0173.1.

Emmitt, G. D., 1978: Tropical cumulus interaction with and modification of the subcloud region. J. Atmos. Sci., 35, 1485-1502, https://doi.org/10.1175/1520-0469 (1978)035<1485:TCIWAM>2.0.CO;2.

—, S. Greco, M. Garstang, and M. Kavaya, 2019: The Doppler Aerosol Wind (DAWN) lidar during CPEX 2017: Performance assessment data processing and data products. Ninth Symp. on Lidar Atmospheric Applications, Phoenix, AZ, Amer. Meteor. Soc., 262, https://ams.confex.com/ams/2019Annual /webprogram/Paper354310.html.

Fairall, C. W., E. F. Bradley, D. P. Rogers, J. B. Edson, and G. S. Young, 1996: Bulk parameterization of air-sea fluxes for TOGA COARE. J. Geophys. Res., 101, 3747-3764, https://doi.org/10.1029/95JC03205.

_ , _ J. E. Hare, A. A. Grachev, and J. B. Edson, 2003: Bulk parameterization of air-sea fluxes: Updates and verification for the COARE algorithm. J. Climate, 16, 571-591, https://doi.org/10.1175/1520-0442 (2003) $016<0571$ :BPOASF $>2.0 . C O ; 2$.

Fitzjarrald, D. R., and M. Garstang, 1981a: Boundary layer growth over the tropical ocean. Mon. Wea. Rev., 109, 1762-1772, https://doi.org/10.1175/1520 -0493(1981)109<1762:BLGOTT>2.0.CO;2.

- and — 1981b: Vertical structure of the tropical boundary layer. Mon. Wea. Rev., 109, 1512-1526, https://doi.org/10.1175/1520-0493(1981)109<1512:VS OTTB $>2.0 . C O ; 2$

Garstang, M., and N. E. LaSeur, 1968: The 1968 Barbados Experiment. Bull. Amer. Meteor. Soc., 49, 627-635, https://doi.org/10.1175/1520-0477-49.6.627. 
- and K. L. Warsh, 1970: Energy flux measurements at the air-sea interface. J. Mar. Tech., 4, 49-54.

— , N. E. LaSeur, K. L. Warsh, R. Hadlock, and J. R. Petersen, 1970: Atmospheric-oceanic observations in the tropics. Amer. Sci., 58, 482-495.

—, M. Murday, W. R. Seguin, J. D. Brown, and N. E. LaSeur, 1971: Fluctuations in humidity, temperature, and horizontal wind as measured by a subcloud tethered-balloon system. IEEE Trans. Geosci. Electron., 9, 199-208, https://doi.org/10.1109 /TGE.1971.271500.

Greco, S., G. D. Emmitt, M. Garstang, S. Wood, and Z. $\mathrm{Pu}, 2019$ : Doppler Aerosol Wind (DAWN) lidar from CPEX 2017: Convective process studies and comparisons with other wind measurement sensors and numerical models. 23rd Conf. Integrated Observing and Assimilation Systems for the Atmosphere, Oceans and Land Surface, Phoenix, AZ, Amer. Meteor. Soc., 520, https://ams.confex.com/ams/2019Annual /webprogram/Paper354294.html.

Grose, P. L., K. L. Warsh, and M. Garstang, 1972a: Dispersion relations and wave shapes. J. Geophys. Res., 77, 3902-3905, https://doi.org/10.1029/JC077i021 p03902.

,-- , and,$- 1972 \mathrm{~b}$ : Wave spectra with directional aspects from deep water in the tropical Atlantic. Dtsch. Hydrogr. Z., 25, 164-178, https://doi .org/10.1007/BF02312701.

Holland, J. Z., 1971: Interim report on results from the BOMEX core experiment. BOMEX Bulletin, No. 10, BOMAP Office, Rockville, MD, 31-43.

- , and E. M. Rasmussen, 1973: Measurements of the atmospheric mass, energy, and momentum budgets over a 500-kilometer square of tropical ocean. Mon. Wea. Rev., 101, 44-55, https://doi.org/10.1175/1520 -0493(1973)101<0044:MOTAME>2.3.CO;2.

Houze, R. A., Jr., 1977: Structure and dynamics of a tropical squall-line system. Mon. Wea. Rev., 105, 15401567, https://doi.org/10.1175/1520-0493(1977)105 $<1540$ :SADOAT $>2.0 . \mathrm{CO} ; 2$.

Johnson, R. H., P. E. Ciesielski, and J. A. Cotturone, 2001: Multiscale variability of the atmospheric mixed layer over the western Pacific warm pool. J. Atmos. Sci., 58, 2729-2750, https://doi.org/10.1175/1520 -0469(2001)058<2729:MVOTAM>2.0.CO;2.

LeMone, M. A., and E. J. Zipser, 1980: Cumulonimbus vertical velocity events in GATE. Part I: Diameter, intensity and mass flux. J. Atmos. Sci., 37, 2444-2457, https://doi.org/10.1175/1520-0469(1980)037<2444:CV VEIG>2.0.CO;2.

Lindzen, R. S., and T. Matsuno, 1968: On the nature of large-scale wave disturbances in the equatorial lower stratosphere. J. Meteor. Soc. Japan, 46, 215-221.
Madden, R. A., and E. J. Zipser, 1970: Multi-layered structure of the wind over the equatorial Pacific during the Line Islands Experiment. J. Atmos. Sci., 27, 336-342, https://doi.org/10.1175/1520-0469(1970)027<0336:ML SOTW>2.0.CO;2.

Malkus, J. S., 1962: Interactions of properties between sea and air. Physical Oceanography, M. N. Hill, Ed., The Sea-Ideas and Observations on Progress in the Study of the Seas, Vol. 1, John Wiley and Sons, 88-294.

Newton, C. W., 1950: Structure and mechanism of the prefrontal squall line. J. Meteor., 7, 210-222, https:// doi.org/10.1175/1520-0469(1950)007<0210:SAMOT $\mathrm{P}>2.0 . \mathrm{CO} ; 2$.

Perry, J. S., 1975: The Global Atmospheric Research Program. Rev. Geophys., 13, 661-667, https://doi .org/10.1029/RG013i003p00661.

Persson, P. O. G., J. E. Hare, C. W. Fairall, and W. D. Otto, 2005: Air-sea interaction processes in warm and cold sectors of extratropical cyclonic storms observed during FASTEX. Quart. J. Roy. Meteor. Soc., 131, 877-912, https://doi.org/10.1256/qj.03.181.

Potter, H., H. C. Graber, N. J. Williams, C. O. Collins III, R. J. Ramos, and W. M. Drennan, 2015: In situ measurements of momentum fluxes in typhoons. J. Atmos. Sci., 72, 104-118, https://doi.org/10.1175 /JAS-D-14-0025.1.

Riehl, H., and Coauthors, 1951: The northeast trade in the Pacific Ocean. Quart. J. Roy. Meteor. Soc., 77, 598-626, https://doi.org/10.1002/qj.49707733405.

Seguin, W. R., and M. Garstang, 1971: A comparison of meteorological sensors used on the USCGC Discoverer during the 1968 Barbados experiment. Bull. Amer. Meteor. Soc., 52, 1071-1076, https://doi .org/10.1175/1520-0477(1971)052<1071:ACOMSU $>2.0 . \mathrm{CO} ; 2$.

- , and — 1976: Some evidence of the effects of convection on the structure of the tropical subcloud layer. J. Atmos. Sci., 33, 660-666, https://doi .org/10.1175/1520-0469(1976)033<0660:SEOTEO $>2.0 . \mathrm{CO} ; 2$.

Smith, S. D., 1980: Wind stress and heat flux over the ocean in gale force winds. J. Phys. Oceanogr., 10, 709-726, https://doi.org/10.1175/1520-0485 (1980)010<0709:WSAHFO>2.0.CO;2.

Telford, J. W., and J. Warner, 1964: Fluxes of heat and water vapor in the lower atmospheric derived from aircraft observations. J. Atmos. Sci., 21, 539-548, https://doi.org/10.1175/1520-0469(1964)021<0539:FO HAVI $>2.0 . \mathrm{CO} ; 2$.

Ulanski, S. I., and M. Garstang, 1978a: The role of surface divergence and vorticity in the cycle of convective rainfall. Part I: Observations and analysis. J. Atmos. 
Sci., 35, 1047-1062, https://doi.org/10.1175/1520 -0469(1978)035<1047:TROSDA >2.0.CO;2.

$\longrightarrow$, and,$- 1978 \mathrm{~b}$ : The role of surface divergence and vorticity in the cycle of convective rainfall. Part II: Descriptive model. J. Atmos. Sci., 35, 1063-1069, https://doi.org/10.1175/1520-0469(1978)035<1063:TR OSDA $>2.0 . \mathrm{CO} ; 2$.

- , and — $1978 \mathrm{c}$ : Some aspects of Florida convective rainfall. Water Resour. Res., 14, 1133-1139, https://doi.org/10.1029/WR014i006p01133.

Warner, J., and J. W. Telford, 1963: Some patterns of convection in the lower atmosphere. J. Atmos. Sci., 20, 313-318, https://doi.org/10.1175/1520-0469(1963)020 $<0313$ :SPOCIT>2.0.CO;2.

Warsh, K., and M. Garstang, 1970: Energy flux measurements at the air-sea interface. J. Mar. Tech., 4, 49-54.

,-- , and P. Grose, 1970: An air-sea interaction deep-ocean buoy. J. Mar. Res., 28, 99-112.

— , P. L. Grose, and M. Garstang, 1972a: Measurement of surface waves in the deep ocean. J. Mar. Tech., 6, 23-28.

— W. A. Brower, and M. Garstang, 1972b: Comparison of sensible and latent heat fluxes computed from measurements by ship and spar buoy in the tropical Atlantic Ocean. Dtsch. Hydrogr. Z., 25, 62-79, https:// doi.org/10.1007/BF02226287.
Yang, M., R. Beale, P. Liss, M. Johnson, B. Blomquist, and P. Nightingale, 2014: Air-sea fluxes of oxygenated volatile organic compounds across the Atlantic Ocean. Atmos. Chem. Phys., 14, 7499-7517, https://doi .org/10.5194/acp-14-7499-2014.

Zipser, E. J., 1969: The role of organized unsaturated downdrafts in structure and rapid decay of an equatorial disturbance. J. Appl. Meteor., 8, 799-814, https:// doi.org/10.1175/1520-0450(1969)008<0799:TROOU $\mathrm{C}>2.0 . \mathrm{CO} ; 2$.

_ 1970: The Line Islands Experiment, its place in tropical meteorology and the rise of the fourth school of thought. Bull. Amer. Meteor. Soc., 51, 1136-1146, https://doi.org/10.1175/1520-0477-51.12.1136.

_ 1977: Mesoscale and convective-scale downdrafts as distinct components of squall-line structure. Mon. Wea. Rev., 105, 1568-1589, https://doi .org/10.1175/1520-0493(1977)105<1568:MACDAD $>2.0 . \mathrm{CO} ; 2$.

- , and M. A. LeMone, 1980: Cumulonimbus vertical velocity events in GATE. Part II: Synthesis and model core structure. J. Atmos. Sci., 37, 2458-2469, https:// doi.org/10.1175/1520-0469(1980)037<2458:CVVEI $\mathrm{G}>2.0 . \mathrm{CO} ; 2$.

\section{NEW FROM AMS BOOKS!}

\section{Synoptic-Dynamic Meteorology Lab Manual Visual Exercises to Complement Midlatitude Synoptic Meteorology}

This lab manual represents a systematic, applied approach to meteorological education that allows well-established theoretical concepts to be used with modernized observational and numerical datasets. Its groundbreaking visualizations elucidate concepts taught in the companion textbook by Gary Lackmann, Midlatitude Synoptic Meteorology.

Gary M. Lackmann, North Carolina State University Brian E. Mapes, University of Miami Kevin R.Tyle, University at Albany, State University of New York

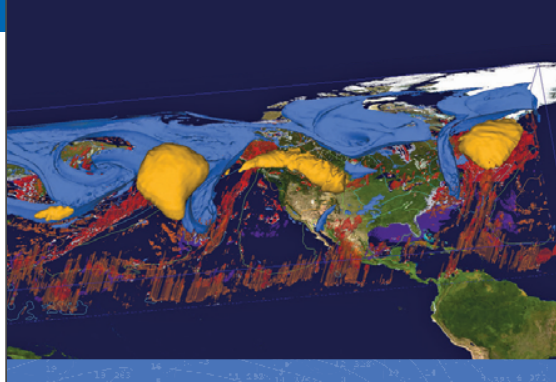

(C) 2017, paperback and ebook, 126 pages ISBN I3: 978-|-878220-26-4 elSBN: 978-I-935704-65-2

AMS Member price: $\$ 60$ Student price: $\$ 50$

Synoptic-Dynamic Meteorology Lab Manual VISUAL EXERCISES TO COMPLEMENT MIDLATITUDE SYNOPTIC METEOROLOGY Gary Lackmann, Brian E. Mapes \& Kevin R. Tyle 


\section{JOIN US FOR THE CULMINATION OF OUR CENTENNIAL CELEBRATION}

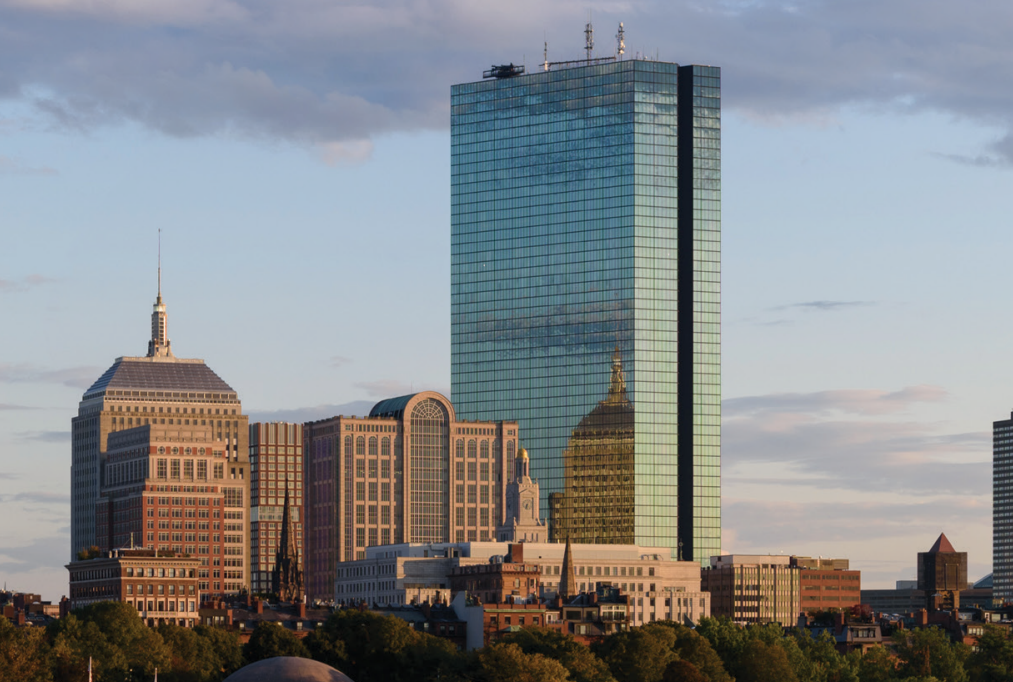

